\title{
ARHITEKTONSKE BARIJERE U SPORTSKIM OBJEKTIMA GRADA RIJEKE
}

\author{
Vita Košpićl, Jasna Lulić Drenjak ${ }^{1}$ \\ ${ }^{1}$ Fakultet zdravstvenih studija Sveučilišta u Rijeci
}

\begin{abstract}
Sažetak
Kada se govori o osobama s invaliditetom, najčešće ih se definira kao osobe s trajnim ograničenjem u obavljanju neke fizičke, ali i psihičke funkcije. Njihov invaliditet posljedica je oštećenja: vida, sluha, govorno-glasovne komunikacije, mišićno-koštanog sustava, središnjeg živčanog sustava i perifernog živčanog sustava. Ovisno o vrsti i težini oštećenja, osoba će se koristiti ortopedskim pomagalom kao što su: invalidska kolica, štake, štap, ortoza, proteza itd. Zgrade i objekti trebaju biti uređeni u skladu s time.

Cilj istraživanja bio je ustanoviti koliko su sportski objekti u gradu Rijeci prilagođeni osobama s invaliditetom. Na osnovi „Pravilnika o osiguranju pristupačnosti građevina osobama s invaliditetom i smanjene pokretljivosti “ iz 2006. godine, određene su arhitektonske komponente koje su bilježene u 15 sportskih objekata. To su: pristup s prometnice i ulaz, komunikacije (dizalo, rampe, podizna platforma), pristup gledalištu i terenu te WC.

Rezultati pokazuju kako 66,67\% riječkih sportskih objekata ima potpuno prilagođen pristup s prometnice i ulaz. Ustanovljeno je kako 42,86\% ima potpuno prilagođene komunikacije, a isti taj postotak sportskih objekata uopće nema prilagođene komunikacije. Tek 28,57\% sportskih objekata omogućuje osobama s invaliditetom neometan pristup gledalištu ili terenu. Ċak 50\% sportskih objekata nema WC uređen za osobe s invaliditetom, dok nešto manji postotak 42,86\% ima prilagođen WC sukladno propisima. Ovi brojevi ukazuju na potrebu za napretkom $i$ modernizacijom riječkih sportskih objekata te potrebno dizanje svijesti društva o kvalitetnijem uključivanju osoba s invaliditetom u svakodnevne sportske aktivnosti.
\end{abstract}

Ključne riječi: sportski objekti, osobe s invaliditetom, grad Rijeka

\section{Uvod}

Svjetska zdravstvena organizacija je Međunarodnom klasifikacijom oštećenja, onesposobljenosti i ometenosti iz 1980. godine definirala ova tri pojma (1). Oštećenje (eng. impairment) predstavlja bilo kakav gubitak ili odstupanje od normalne psihičke, fiziološke ili anatomske strukture ili funkcije. Onesposobljenost ili invaliditet (engl. disability) je bilo kakvo ograničenje ili nedostatak sposobnosti za obavljanje neke aktivnosti na način ili u opsegu koji se smatra normalnim za ljudsko biće. Ometenost (engl. handicap) je pojam socijalnog karaktera, a rezultira iz oštećenja ili invaliditeta koje osobu ograničava ili joj onemogućuje ispunjenje njene prirodne uloge u društvu (1).

Postoje brojne definicije osoba s invaliditetom. Prema Zakonu o Hrvatskom registru o osobama $\mathrm{s}$ invaliditetom, one su definirane kao osobe s trajnim ograničenjem, smanjenjem ili gubitkom sposobnosti izvršenja neke fizičke aktivnosti ili psihičke funkcije primjerene životnoj dobi, nastale kao posljedica oštećenja zdravlja (2).

Sport uvelike pridonosi mentalnom zdravlju i kvaliteti života onesposobljenim osobama (3). On budi osjećaj zadovoljstva, kako u rehabilitaciji tako i u zajednici. Pridonosi samopouzdanju i boljoj slici o sebi, a istraživanjima je dokazano kako je razina samopouzdanja kod sportaša $\mathrm{s}$ invaliditetom i sportaša opće populacije poprilično jednaka. 
U talijanskom istraživanju Gioie i sur. iz 2006. sudjelovalo je 137 osoba s oštećenjem kralježničke moždine, a rezultati su pokazali značajne razlike u stopi tjeskobe/depresije među osobama u kolicima sedentarnog načina života i onih koji se bave sportom (osobe u kolicima sedentarnog načina života pokazivale su višu razinu tjeskobe) (3). Ove činjenice ukazuju na važnost bavljenja sportom osoba s invaliditetom. Stoga je bitno da imaju omogućen i prilagođen pristup sportskim objektima.

Prema službenoj stranici grada Rijeke, pristup sportskim objektima koji su pod tvrtkom Rijeka sport, prilagođen je osobama $\mathrm{s}$ invaliditetom (4). Međunarodno udruženje za sportske i rekreacijske objekte i Međunarodni olimpijski odbor organiziraju arhitektonske natječaje i dodjeljuju nagrade određenim sportskim i rekreacijskim objektima. 2009. je u Kölnu Bazenima Kantrida uručena brončana medalja za prilagođenost arhitektonskog uređenja osobama $\mathrm{s}$ invaliditetom (5).

\section{Arhitektonske barijere u sportskim objektima grada Rijeke}

Pregledom sportskih i rekreacijskih objekata u gradu Rijeci nastojalo se uvidjeti koliko su oni prilagođeni osobama $\mathrm{s}$ invaliditetom, odnosno koliko arhitektonske barijere u njima ograničavaju normalno funkcioniranje ovih osoba. Kako bi osobe s invaliditetom mogle ostvariti svoje ciljeve i pokazati svoje mogućnosti, ipak bi im trebalo biti omogućeno osnovno kretanje. Osnovama se i mogu nazvati komponente koje su se bilježile u istraživanju - pristup objektu s prometnice, ulaz, pristup terenu i gledalištu, komunikacije te WC. Osoba ne mora nužno sudjelovati u sportskim aktivnostima, ali može prisustvovati kao podrška članu obitelji ili klubu za koji navija. Poražavajući je osjećaj kada se to ne može zbog vanjskih, točnije arhitektonskih barijera.

U 15 riječkih sportskih objekata pregledavale su se gore navedene komponente. Svrstane su u tablicu pod kategorije: prilagođeno, djelomično prilagođeno te neprilagođeno. Ustanovljeno je kako 66,67\% sportskih objekata ima u potpunosti prilagođen pristup s prometnice i ulaz za osobe s invaliditetom. Svega $20 \%$ ima djelomično prilagođen pristup, a 13,33\% ima neprilagođen pristup. To znači da će osobe $\mathrm{s}$ invaliditetom već pri ulazu u nekim sportskim objektima imati poteškoća ili neće moći biti samostalne. U neke nažalost neće moći ni ući.

Komunikacije koje uključuju prilagođene hodnike, dizala, podizne platforme, rampe, taktilne crte vođenja itd. važne su u kretanju sportskim objektima, svladavanju visinskih razlika ili u praćenju puta. Ako su arhitektonski potrebne, određene bi komunikacije trebale biti dijelom objekata. Ustanovljeno je kako je 42,86\% sportskih objekata u Rijeci u potpunosti omogućilo komunikacije osobama s invaliditetom (ili zbog iste razine/vanjskog terena nisu bile potrebne). Isti taj postotak $(42,86 \%)$ sportskih objekata nema prilagođene komunikacije (npr. 44 hodnik) ili ih uopće ne posjeduje, a trebao bi (npr. rampe, dizala, taktilne crte vođenja). Ostatak komunikacija $(14,28 \%)$ je djelomično prilagođen.

Pristup gledalištu, odnosno terenu jedna je od najvažnijih stvari zbog kojih se uopće dolazi u neki sportski i rekreacijski objekt. Zato bi trebao biti prilagođen osobama s invaliditetom. Međutim, tek 28,57\% svih sportskih objekata ima u potpunosti prilagođen pristup gledalištu, odnosno terenu. Djelomično prilagođenih je točno $50 \%$, a neprilagođenih $21,43 \%$. Ova statistika ukazuje na to da u nekim objektima ove osobe ili neće moći pristupiti gledalištu, ili terenu, ili ni jednome. To smanjuje mogućnost izbora sportske aktivnosti neke osobe ili ju ograničava u davanju podrške. U slučaju da joj je blizu baš taj objekt koji nije prilagođen, osoba 
s invaliditetom onda mora birati udaljenije sportsko rekreacijske centre, što je dodatno frustrirajuće.

Posljednja komponenta koja se bilježila bio je WC. On je jedan od osnovnih dijelova svake zgrade i svaki čovjek ima fiziološku potrebu za istim. Treba misliti na to da su nekima invalidska kolica osnovno sredstvo kojim se dolazi do WC-a i da je potrebno osigurati prostor u kojemu će osoba obaviti transfer, moći se kretati, spustiti i podignuti. Zato su propisane obavezne dimenzije, npr. visina kvake, udaljenost WC školjke od umivaonika i vratiju te obavezna dva držača. Manje od $50 \%$ objekata ima u potpunosti prilagođen WC $(42,86 \%)$. Zabrinjavajuća je činjenica da čak 50\% sportskih objekata uopće nema prilagođen WC za osobe s invaliditetom, a 7,14\% ima djelomično prilagođen WC.

Stupčasti dijagram: Pristupačnost sportskih objekata osobama s invaliditetom

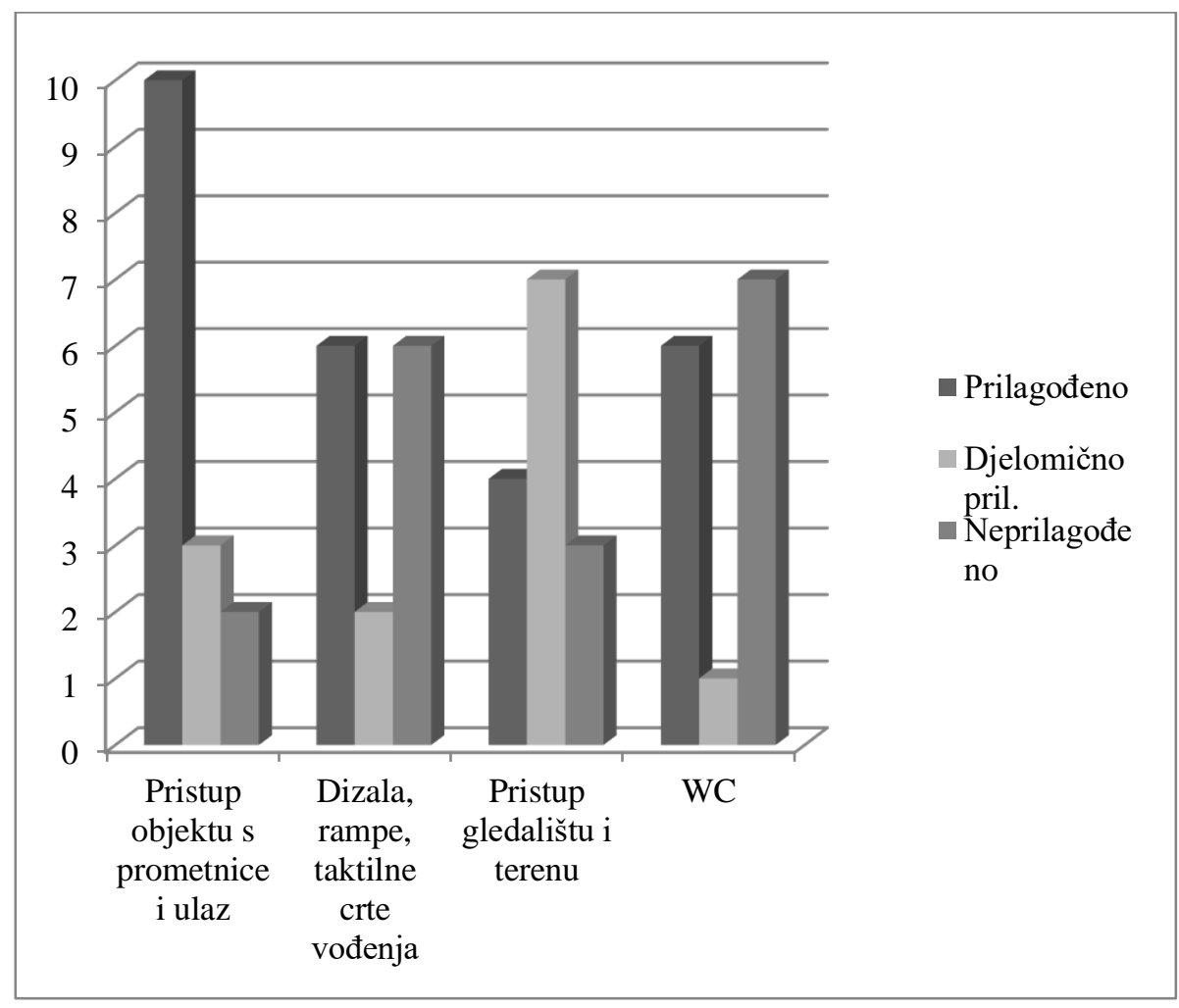

Ono što se dalo primijetiti tijekom istraživanja je povezanost prilagođenosti sportskog objekta osobama s invaliditetom i godina izgradnje objekta. Naime, moderniji objekti ili oni koji su naknadno obnovljeni, u potpunosti su prilagođeni ili imaju nadograđene i/ili adaptirane elemente. Atletska dvorana Kantrida izgrađena je 2010. i u potpunosti prilagođena kao i bazeni Kantrida, izgrađeni 2008. Dobar primjer je i Centar Zamet izgrađen 2009. koji je također u potpunosti prilagođen osobama $\mathrm{s}$ invaliditetom. Otvoreno igralište Kampus obnovljeno je 2015., a osobe s invaliditetom mogu bez problema sudjelovati u sportskim aktivnostima. Starije građevine su neprilagođenije. Sportsko rekreacijski centar 3. Maj izgrađen je 1985. i pun je arhitektonskih barijera. Boćarski centar Podvežica izgrađen je 1911., ali zadnja obnova bila je 2006. godine kada se nabavila mobilna rampa za osobe s invaliditetom. Sportsko rekreacijski centar Mlaka izgrađen je 1971. godine i nije prilagođen za osobe s invaliditetom kao ni košarkaška dvorana Brajda, izgrađena 2003. 


\section{Zaključak}

Čovjek je biće kretanja. Osobama kod kojih je kretanje ograničeno ili potpomognuto ortopedskim pomagalom arhitektonske barijere predstavljaju problem u svakodnevnom funkcioniranju. Žele li sudjelovati, prisustvovati nekom sportu ili bodriti najdraži klub, moraju imati adekvatan pristup sportskom objektu. Osnovni elementi pristupačnosti su: pristup s prometnice, ulaz u objekt, pristup terenu i gledalištu i WC.

Svi sportski objekti grada Rijeke nemaju u potpunosti prilagođen ulaz za osobe s invaliditetom, a manje od pola obrađenih objekata ima u potpunosti omogućen pristup gledalištu, terenu ili uređen WC. Uočena je povezanost između godine izgradnje i prilagođenosti sportskog objekta. Hrvatska je potpisala Konvenciju o pravima osoba s invaliditetom Ujedinjenih naroda 2007. godine $\mathrm{i}$ njome želi poštivati prava osoba $\mathrm{s}$ invaliditetom u potpunosti. Pravo osobe $\mathrm{s}$ invaliditetom je da kvalitetno provodi svoje slobodno vrijeme, da ulaže u sebe, svoj zdrav duh i tijelo. Ostaje nam nadati se da će u budućnosti biti još novoizgrađenih i adaptiranih postojećih sportskih objekata.

\section{Literatura}

1. Impairment, Disability and Handicap. Emory University School of Medicine. Dostupno na: https://med.emory.edu/departments/pediatrics/divisions/neonatology/dpc/impairmentmx.html Pristupljeno 03.06.2020.

2. Zakon o Hrvatskom registru o osobama s invaliditetom. Narodne novine, br. 64/01.

3. Blauwet C, Willick SE. The Paralympic Movement: Using Sports to Promote Health, Disability Rights, and Social Integration for Athletes With Disabilities. American Academy of Physical Medicine and Rehabilitation. 2012;4(11):851-856. Dostupno na:

https://onlinelibrary.wiley.com/doi/abs/10.1016/j.pmrj.2012.08.015

4. Grad Rijeka. Pristupačni objekti i lokacije za osobe s invaliditetom. Dostupno na: https://www.rijeka.hr/teme-za-gradane/obitelj-i-drustvena-skrb/osobe-

sinvaliditetom/osiguravanje-mobilnosti-pristupacnosti/pristupacni-objekti-i-lokacije-zaosobes-invaliditetom/ Pristupljeno: 03.06.2020.

5. Rijeka sport. Međunarodna arhitektonska nagrada Bazenima Kantrida. Dostupno na: https://www.rijekasport.hr/node/212_Pristupljeno 03.06.2020. 